\title{
Effect of Aerobic Exercise on Cognition, Academic Achievement, and Psychosocial Function in Children: A Systematic Review of Randomized Control Trials
}

\author{
Caitlin Lees, MD, MA; Jessica Hopkins, MD, MHSc
}

Suggested citation for this article: Lees C, Hopkins J. Effect of Aerobic Exercise on Cognition, Academic Achievement, and Psychosocial Function in Children: A Systematic Review of Randomized Control Trials. Prev Chronic Dis 2013;10:130010. DOI: http://dx.doi.org/10.5888/pcd10.130010国

PEER REVIEWED

\begin{abstract}
\section{Introduction}

Although the effects of aerobic physical activity (APA) on children's physical health is well characterized, the effect of aerobic physical activity on cognition, academic achievement, and psychosocial function has not yet been established. This systematic review provides an overview of research elucidating the relationship between aerobic physical activity and children's cognition, academic achievement, and psychosocial function.
\end{abstract}

\section{Methods}

A systematic review of English articles was performed in April 2013 using MEDLINE, Cochrane, PsycINFO, SPORTDiscus, and EMBASE. Additional studies were identified through back-searching bibliographies. Only randomized control trials with an intervention of aerobic physical activity in children younger than 19 years that measured psychological, behavioral, cognitive, or academic outcomes were included.

\section{Results}

We found 8 relevant randomized control trials that met our inclusion criteria and extracted relevant data and evaluated the methodologic quality of the studies. Of the 8 studies identified, 2 studies were crossover randomized control trials studying the effects of acute aerobic physical activity on cognitive performance. Six studies were parallel-group randomized control studies, of which only 2 had a follow-up period of longer than 6 months. All studies showed that APA had a generally positive impact on children's cognition and psychosocial function. However, this relationship was found to be minimal in many studies and in some measures, no significant improvement was seen at all. There was no documentation of APA having any negative impact on children's cognition and psychosocial health, even in cases where school curriculum time was reassigned from classroom teaching to aerobic physical activity.

\section{Conclusion}

APA is positively associated with cognition, academic achievement, behavior, and psychosocial functioning outcomes. More rigorous trials with adequate sample sizes assessing the impact of APA on children's cognitive abilities, psychosocial functioning, behavior, and academic achievement are needed, with standardized interventions, valid and reliable tools of measurement, and long-term follow-up for sustained cognitive and psychosocial outcomes.

\section{Introduction}

The global trend of rising childhood obesity has become increasingly prominent; $21.4 \%$ of youth aged 5 to 17 years in Organization for Economic Co-operation and Development (OECD) countries were considered overweight or obese on the basis of 2011 data (1). This proportion represents a significant increase from previous generations. For example, in Canada the percentage of youth aged 5 to 17 years considered overweight or obese from 2009 through 2011 was $31.5 \%$, more than double the $15 \%$ of youth aged o to 17 years in 1978 and 1979 (2). Along with poor diet and an obesogenic environment, inadequate physical activity is considered a key factor (3,4). On average, only $20 \%$ of children in OECD countries participate in moderate to vigorous physical activity daily (5). One study of The Canadian Health Measures Survey, which used accelerometers to objectively monitor physical activity, found that only $7 \%$ of children (a nationally representative sample aged 6-19y) engaged in 60 minutes of moderate to vigorous physical activity daily at least 6 days per week, based on Canadian Physical Activity Guidelines $(6,7)$.

The benefits of physical activity on health outcomes have been documented $(8,9)$. However, the cognitive and psychosocial effects of aerobic physical activity (APA) on children are not well understood. Rasberry et al conducted a systematic review on the relationship between school-based physical activity and academic performance (10). Their review, although comprehensive, included many crosssectional studies and studies that did not specify the type (aerobic vs non-aerobic) or dose (duration, frequency) of physical activity, making it challenging to infer optimal conditions for physical activity to enhance academic performance. Singh et al also conducted a systematic review, which focused on the longitudinal relationship between physical activity and academic performance using only 
prospective data (11). Although the positive association between physical activity and performance at school in longitudinal studies is supportive of a causal effect, many studies did not qualify the type or dose of physical activity. This omission is relevant, given the evidence that aerobic-based physical activity generates structural changes in the brain, such as neurogenesis, angiogenesis, increased hippocampal volume, and connectivity $(12,13)$. In children, a positive relationship between aerobic fitness, hippocampal volume, and memory has been found (12,13). Animal and human studies have demonstrated that regular APA induces physiologic adaptations, such as an increase in blood volume, improved fat mobilization, and thermoregulation (13). More recently, the effect of APA on the brain has been studied in detail. The brain also demonstrates structural changes in response to regular APA (12,13). In particular, structural changes to the hippocampus have been observed that have implications for memory and stress regulation $(12,13)$. Neurogenesis and increased white matter connectivity have also been observed in some studies in response to APA (13). Physiologic changes resulting from APA suggest an adaptive plasticity that could be harnessed to improve physical fitness, cognition, academic achievement, and psychosocial function. Given this relationship and the need to build on previous reviews with more specific information on the physical activity intervention, we focused on APA interventions and their effect on children's cognitive function, academic achievement, and psychosocial function, with consideration of methodologic quality.

\section{Methods}

\section{Data sources}

In April 2013, we performed a computerized search of 5 large electronic databases - MEDLINE, SPORTDiscus, EMBASE, Cochrane, and PsycINFO - including results from all years available. Two elements were used in the search strategy, the first being for APA (eg, physical activity, aerobic exercise, or cardiovascular health) and the second being measures of cognitive and psychological outcomes (eg, health, mental health, cognition, achievement, intelligence tests, intelligence). The specific search terms used varied slightly in each database so as to make use of MeSH terms or subheadings. More specific keywords such as "aerobic" were at times subsumed by these headings and thus not included, and search terms were kept purposefully broad to ensure that relevant results were not excluded. Population was limited to children (younger than 19 years) either through the search limitations available or through keywords (eg, children, teens, child, students). Studies were limited to English (Appendix).

\section{Definitions}

We used the Centers for Disease Control and Prevention's Physical Activity Glossary of Terms (14). APA, which is intended to improve cardiorespiratory fitness, can be defined as "activity in which the body's large muscles move in a rhythmic manner for a sustained period of time" (14). Exercise is considered a "subcategory of physical activity that is planned, structured, repetitive, and purposive in the sense that the improvement or maintenance of one or more components of physical fitness is the objective" (14). Physical activity is "any bodily movement produced by the contraction of skeletal muscle that increases energy expenditure above a basal level" (14). This differs from physical fitness, which is "the ability to carry out daily tasks with vigor and alertness, without undue fatigue, and with ample energy to enjoy leisure-time pursuits and respond to emergencies" (14).

Outcomes were grouped in the categories of mental health, behavior, and cognition. The World Health Organization defines mental health as not merely the absence of disease but "a state of well-being in which every individual realizes his or her own potential, can cope with the normal stresses of life, can work productively and fruitfully, and is able to make a contribution to her or his community" (15). We looked for studies with outcomes related to mental health disorders, such as mood disorders (eg, depression, anxiety) or attention deficit hyperactivity disorder. Behavior, in the context of this study, was used to refer specifically to behaviors that may promote or disrupt learning in the school setting, through actions, speech, or distraction. Lastly, cognition was defined as a student's ability to learn through perception, reasoning, analysis, and judgment, which is commonly measured in schools through the use of objective tests, whereas academic achievement referred to a student's performance on school-related work or tasks (eg, standardized tests, grades).

\section{Study selection}

Studies of interest included those with a population younger than 19 years with an APA intervention. Inclusion and exclusion criteria were agreed on by both authors. Only randomized controlled trials were included to minimize biases between intervention and control groups and to support the causal role of the intervention. Outcomes were included only if they involved a measure of mental health, behavior, discipline, or cognition. Studies were excluded if the results measured only fitness or the success of health promotion (adherence to regimes and participation), or if the study measured only health outcomes specific to a disease state.

The search strategy guided the flow of articles through the review process (Figure) and returned 1,233 results. The citation lists for review articles and meta-analyses were back-searched for relevant articles that may have been missed by the search strategy, resulting in 12 potentially germane articles for a total of 1,245. After duplicates were excluded, there were 1,200 unique articles. A total of 1,113 results were immediately excluded according to our criteria. After further reading, we excluded a remaining 4 for focusing exclusively on an obese population, 16 for also being reviews or meta-analyses, 9 for having a pretest/posttest study design, 44 for having a crosssectional study design, and 6 for various other reasons. This resulted in a total of 1,192 studies excluded. 


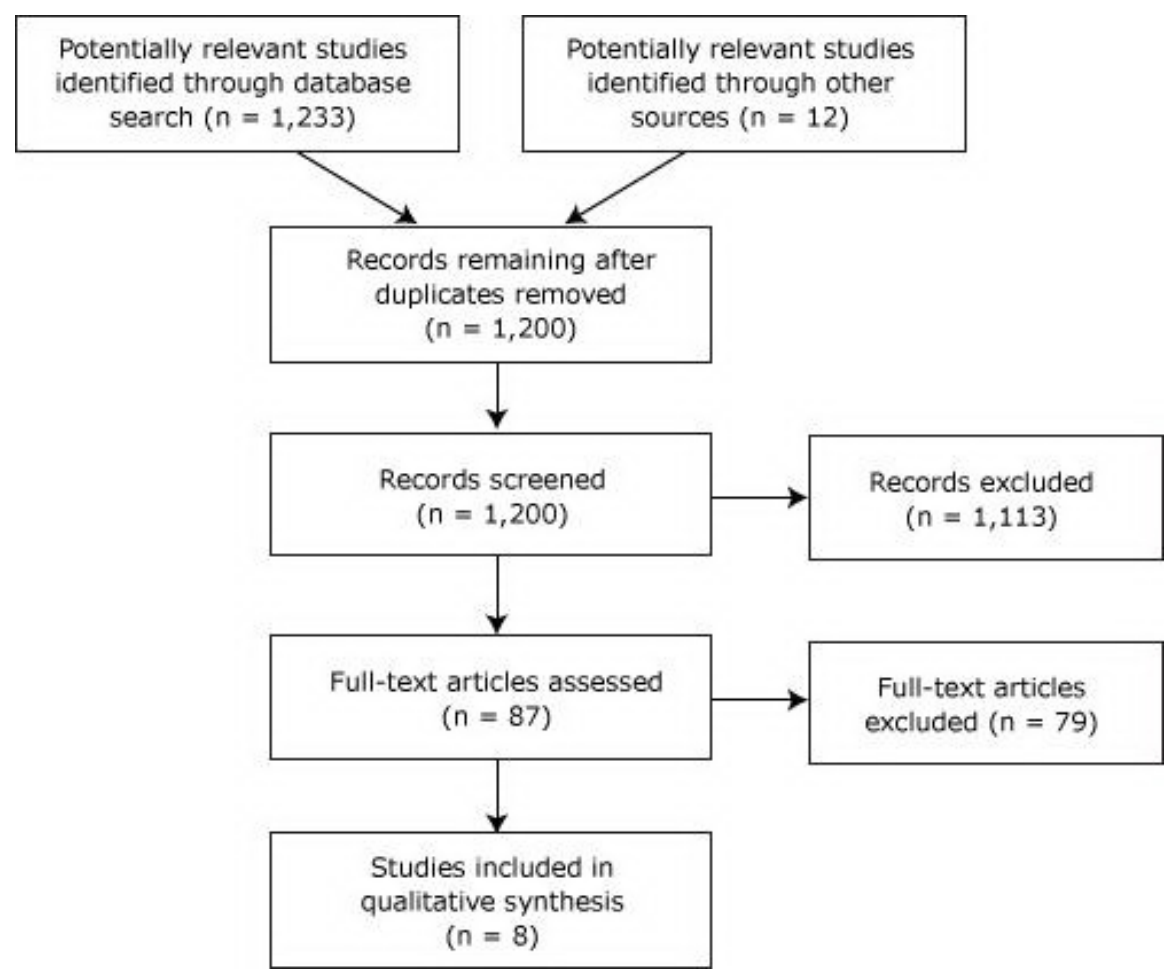

Figure. Flow of articles through the review process. [A text description of this figure is also available.]

\section{Data extraction}

Data were extracted and abstracted by a single author (C. L.). Any uncertainties regarding article categorization or data abstraction were resolved by consensus between authors. Article validity was assessed through a standardized critical appraisal tool, the Jadad Scale (16), which on systematic review was shown to have the best validity and reliability evidence of numerous scales evaluated, including the Delphi List and CONSORT Scale (17). The Jadad Scale focuses on 3 criteria that have been shown to correlate with bias: randomization, blinding, and an account of all participants. The scale ranges from o to 5; studies less subject to bias score higher.

\section{Results}

We selected studies on the basis of study design, country, follow-up duration, characteristics of participants at baseline, type of APA, outcome measures, and main results (Table 1) and analyzed the studies' strengths and weaknesses (Table 2). Although the outcomes measured were heterogeneous, all studies showed that APA had a generally positive effect on children. There was no documentation of any negative outcome resulting from APA. Shephard (24) noted that APA resulted in slight improvement in academic performance, even when curriculum time was reassigned from traditional education to physical activity. No study analyzed a dose-response relationship between APA and cognitive, mental health, or behavioral outcomes.

Mental health outcomes included reduced depression and increased self-esteem, although no change was found in anxiety levels (18). Tuckman et al found a positive effect on creative capacity but no change in behavior or perceptual functioning (26). Similarly, Stroth et al found no consistent effect of acute APA on inattention or impulsivity; however, they did note that subjects who were already more fit (and ostensibly participated in APA more frequently) did perform better (25).

All 4 studies that measured academic achievement or cognitive performance noted enhanced performance in the APA intervention group. One of the longest running studies measured academic performance over 6 years and found a small improvement in academic performance in children from grades 1 through 6 (24). Hill and colleagues' (21) short crossover trial showed short-term improvement on cognitive performance, but the authors admitted that their research methods may have had this effect because APA enhanced participants' use of memory from practice. Donnelly et al (19) found significant improvements in academic achievement over 3 years of follow-up in schools with APA programs, and Reed et al (22) found that children participating in APA, even engaging only in moderateintensity APA as measured by pedometers (23), performed significantly better on intelligence testing and state tests on social studies. Scores were noted to be higher on English/language arts, math, and science tests, but the results were not significant.

\section{Discussion}

This systematic review of the literature found that APA is positively associated with cognition, academic achievement, behavior, and psychosocial functioning outcomes. Importantly, Shephard also showed that curriculum time reassigned to APA still results in a measurable, albeit small, improvement in academic performance (24). This finding lends support to the theories that APA and curricular time need not be a trade-off, that there is a synergistic effect between APA and academic performance, and that educators and policy makers can be reassured that spending time in APA does not detract from academic achievement.

Strengths of this review included its systematic approach and thorough, replicable search strategy. This study builds on previous reviews by using methodologically stronger study designs that support causal hypotheses and standardized measures of APA and 
outcomes. We excluded studies that examined specific populations, notably overweight or obese children, in an attempt to reduce potentially confounding factors and to allow for generalizability at a population level. Although studies that used self-reported academic achievement or cognitive scores were not part of the original inclusion/exclusion criteria, no studies were included that did, which significantly improves validity.

This systematic review was limited by the available studies. This study did not include either unpublished research findings or nonEnglish studies, which may have resulted in the loss of relevant research. Publication bias may also have resulted in relevant studies (especially those demonstrating an equivocal outcome) not being published. Although the similar outcomes of cognition, academic achievement, and psychosocial functioning were measured in all of the studies, measurement tools were inconsistent between studies, and some lacked validity data (Table 2). Academic achievement does not necessarily correlate with cognitive ability, although presumably there may be some overlap in areas of perception, reasoning, analysis, and judgment. In some cases, studies were also limited by small participant numbers (underpowered) and short follow-up times. Additionally, only 1 study explored mental healthrelated outcomes (18).

Although this review cannot provide a definitive answer to the question of whether APA leads to improved cognition, academic achievement, behavior, and psychosocial functioning, the results of a positive association are promising and worthy of future, more rigorous study. APA interventions in a school-based setting are complex to administer. A perfectly designed randomized control trial may be limited by generalizability to other settings. By using the information obtained from a diverse set of interventions and outcome measures, some interesting patterns emerge. The actual aerobic-based activity does not appear to be a major factor; interventions used many different types of APA and found similar associations. In positive association studies, intensity of the aerobic activity was moderate to vigorous. The amount of time spent in APA varied significantly between studies; however, even as little as 45 minutes per week appeared to have a benefit.

Although all of these areas require further study, our findings can inform educators and policy makers as they work to justify, support, and integrate APA into the regular school curriculum. Future study should focus on the dose-response relationship between APA and cognitive or psychosocial outcomes and the optimum frequency of bouts of APA, neither of which has been adequately investigated. More rigorous trials with adequate sample sizes assessing the effect of APA on children's cognitive abilities, psychosocial functioning, behavior, and academic achievement are needed, with standardized interventions, valid and reliable tools of measurement, and longterm follow-up for sustained cognitive and psychosocial outcomes.

\section{Author Information}

Corresponding Author: Jessica Hopkins, MD, MHSc, Associate Medical Officer of Health, Niagara Region Public Health, Niagara Region Public Health, 2201 St. David's Rd, PO Box 1052, Thorold, ON L2V oA2. Telephone: 905-688-8248. E-mail:

jessica.hopkins@niagararegion.ca.

Author Affiliations: Caitlin Lees, Dalhousie University, Halifax, Nova Scotia. At the time of this study, Dr Lees was a student at McMaster University, Hamilton, Ontario. Dr Hopkins is an assistant professor of Clinical Epidemiology and Biostatistics, McMaster University, Hamilton, Ontario.

\section{References}

1. Obesity update 2012. OECD; 2012. http://www.oecd.org/health/49716427.pdf. Accessed May 6, 2013.

2. Roberts KC, Shields M, de Groh M, Aziz A, Gilbert J. Overweight and obesity in children and adolescents: results from the 2009 to 2011 Canadian Health Measures Survey. 82-003-X Vol. 23 No. 3. Statistics Canada; 2012.

3. Population-based approaches to childhood obesity prevention. World Health Organization; 2012. http://www.who.int/dietphysicalactivity/childhood/WHO_new_childhoodobesity_PREVENTION_27nov_HR_PRINT_OK.pdf. Accessed May 6, 2013.

4. 2008 Physical activity guidelines for Americans. US Department of Health and Human Services; 2008. http://www.health.gov/paguidelines/pdf/paguide.pdf. Accessed May 6, 2013.

5. Physical activity at ages 11, 13, and 15. OECD; 2011. http://www.oecd.org/els/family/48968019.pdf. Accessed May 6, 2013.

6. Colley RC, Garriguet D, Janssen I, Craig CL, Clarke J, Tremblay MS. Physical activity of Canadian children and youth: accelerometer results from the 2007 to 2009 Canadian Health Measures Survey. Health Rep 2011;22(1):15-23. PubMed 圈

7. Tremblay MS, Kho ME, Tricco AC, Duggan M. Process description and evaluation of Canadian Physical Activity Guidelines development. Int J Behav Nutr Phys Act 2010;7:42. CrossRef 罗 PubMed 茴

8. Janssen I, LeBlanc AG. Systematic review of the health benefits of physical activity and fitness in school-aged children and youth. Int J Behav Nutr Phys Act 2010;7:40. CrossRef 国 PubMed 圈

9. Warburton DE, Nicol CW, Bredin SS. Health benefits of physical activity: the evidence. CMAJ 2006;174(6):801-9. CrossRef 圈 PubMed 橉

10. Rasberry CN, Lee SM, Robin L, Laris BA, Russell LA, Coyle KK, et al. The association between school-based physical activity, including physical education, and academic performance: a systematic review of the literature. Prev Med 2011;52(Suppl 1):S1020. CrossRef 輏 PubMed 圈

11. Singh A, Uijtdewilligen L, Twisk JWR, van Mechelen W, Chinapaw MJ. Physical activity and performance at school: a systematic review of the literature including a methodological quality assessment. Arch Pediatr Adolesc Med 2012;166(1):49-55. CrossRef $\mathrm{Q}$ PubMed 匡 
12. Chaddock L, Erickson KI, Prakash RS, Kim JS, Voss MW, Vanpatter M, et al. A neuroimaging investigation of the association between aerobic fitness, hippocampal volume, and memory performance in preadolescent children. Brain Res 2010;1358:172-83. CrossRef 圈 PubMed 圈

13. Thomas AG, Dennis A, Bandettini PA, Joahsen-Berg H. The effects of aerobic activity on brain structure. Front Psychol 2012;3:86. CrossRef 圈 PubMed 圈

14. Physical activity glossary of terms. Centers for Disease Control and Prevention; 2011. http://www.cdc.gov/physicalactivity/everyone/glossary/. Accessed May 6, 2013.

15. What is mental health? World Health Organization; 2007. http://www.who.int/features/qa/62/en/index.html. Accessed May 6, 2013.

16. Jadad AR, Moore RA, Carroll D, Jenkinson C, Reynolds DJ, Gavaghan DJ, et al. Assessing the quality of reports of randomized

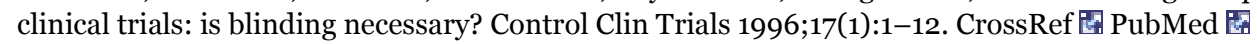

17. Olivo SA, Macedo LG, Gadotti IC, Fuentes J, Stanton T, Magee DJ. Scales to assess the quality of randomized controlled trials: a systematic review. Phys Ther 2008;88(2):156-75. CrossRef 国 PubMed 圈

18. Crews DJ, Lochbaum MR, Landers DM. Aerobic physical activity effects on psychological well-being in low-income Hispanic children. Percept Mot Skills 2004;98(1):319-24. CrossRef 圈 PubMed 因

19. Donnelly JE, Greene JL, Gibson CA, Smith BK, Washburn RA, Sullivan DK, et al. Physical Activity Across the Curriculum (PAAC): a randomized controlled trial to promote physical activity and diminish overweight and obesity in elementary school children. Prev Med 2009;49(4):336-41. CrossRef 圈 PubMed 专

20. Fisher A, Boyle JM, Paton JY, Tomporowski P, Watson C, McColl JH, et al. Effects of a physical education intervention on cognitive function in young children: randomized controlled pilot study. BMC Pediatr 2011;11:97. CrossRef 圈 PubMed 圈

21. Hill LJ, Williams JH, Aucott L, Thomson J, Mon-Williams M. How does exercise benefit performance on cognitive tests in primary-school pupils? Dev Med Child Neurol 2011;53(7):630-5. CrossRef 圈 PubMed 圈

22. Reed JA, Einstein G, Hahn E, Hooker SP, Gross VP, Kravtiz J. Examining the impact of integrating physical activity on fluid intelligence and academic performance in an elementary school setting: a preliminary investigation. J Phys Act Health 2010;7 (3):343-51. PubMed 企

23. Centers for Disease Control and Prevention. Vital signs: walking among adults - United States, 2005 and 2010. MMWR Morb Mortal Wkly Rep 2012;61(31):595-601. PubMed 圈

24. Shephard RJ. Habitual physical activity and academic performance. Nutr Rev 1996;54(4 Pt 2):S32-6. PubMed 国

25. Stroth S, Kubesch S, Dieterie K, Ruchsow M, Heim K, Kiefer M. Physical fitness, but not acute exercise modulates event-related potential indices for executive control in healthy adolescents. Brain Res 2009;1269:114-24. CrossRef 圈 PubMed 国

26. Tuckman BW, Hinkle JS. An experimental study of the physical and psychological effects of aerobic exercise on schoolchildren. Health Psychol 1986;5(3):197-207. CrossRef 圈 PubMed 圈

27. McDowell I. Measuring health: a guide to rating scales and questionnaires New York (NY): Oxford University Press; 2006. p. 33542.

28. Kaplan RM, Saccuzzo DP. Psychological testing: principles, applications, and issues. Belmont: Wadsworth Cengage Learning; 2008. p. 336-7, 373-4, 482-3.

29. Strauss E, Sherman EMS, Spreen O. A compendium of neuropsychological tests: administration, norms, and commentary. New York (NY): Oxford University Press; 2006. p. 133-44, 229-36, 370-83.

30. Frick PJ, Barry CT, Kamphaus RW. Clinical assessment of child and adolescent personality and behavior. New York (NY): Springer; 2009. p. 170-4.

31. Ruchsow M, Spitzer M, Gron G, Grothe J, Kiefer M. Error processing and impulsiveness in normals: evidence from event-related potentials. Brain Res Cogn Brain Res 2005;24(2):317-25. CrossRef 居 PubMed 國

\section{Tables}

Table 1. Randomized Controlled Trials Reporting Children's Cognitive and Psychosocial Outcomes After Increased Aerobic Activity

\begin{tabular}{|l|l|l|l|l|l|}
\hline Source & $\begin{array}{c}\text { Sesign/Country/Follow } \\
\text {-up Duration }\end{array}$ & $\begin{array}{l}\text { Characteristics of } \\
\text { Study Sample at } \\
\text { Baseline }\end{array}$ & Measure of APA & Measure of Outcome & \multicolumn{1}{|c|}{ Main Results } \\
\hline $\begin{array}{l}\text { Crews et } \\
\text { al } 2004 \\
(18)\end{array}$ & $\begin{array}{l}\text { RCT/United States/6 } \\
\text { weeks }\end{array}$ & $\begin{array}{l}\text { 66 Grade 4 (aged } \\
8-10 \text { y) Hispanic } \\
\text { students in a low- } \\
\text { income school } \\
\text { district, 33 boys } \\
\text { and 33 girls }\end{array}$ & $\begin{array}{l}\text { Aerobic physical } \\
\text { activity with an } \\
\text { intensity equal or } \\
\text { greater than } 60 \% \\
\text { of maximum heart } \\
\text { rate reserve }\end{array}$ & $\begin{array}{l}\text { State-Trait Anxiety } \\
\text { Inventory (STAI), Beck } \\
\text { Depression Inventory, } \\
\text { Rosenberg's Scale }\end{array}$ & $\begin{array}{l}\text { Children participating in } \\
\text { an aerobic exercise } \\
\text { program of 20 minutes, 3 } \\
\text { times per week, reported } \\
\text { significantly less } \\
\text { depression and greater } \\
\text { self-esteem, but no } \\
\text { difference on trait anxiety. }\end{array}$ \\
\hline $\begin{array}{l}\text { Donnelly } \\
\text { et al } 2009 \\
\text { (19) }\end{array}$ & RCT/United States/3 years & $\begin{array}{l}527 \text { Grades 2 and } \\
3 \text { students (aged 6 } \\
-9 \mathrm{y})\end{array}$ & $\begin{array}{l}45 \text { or More minutes } \\
\text { per week of } \\
\text { moderate to }\end{array}$ & $\begin{array}{l}\text { Wechsler Individual } \\
\text { Achievement Test, 2nd } \\
\text { edition (WIAT-II) }\end{array}$ & $\begin{array}{l}\text { Significant improvements } \\
\text { in academic achievement } \\
\text { from baseline to 3 years }\end{array}$
\end{tabular}




\begin{tabular}{|c|c|c|c|c|c|}
\hline Source & $\begin{array}{c}\text { Study } \\
\text { Design/Country/Follow } \\
\text {-up Duration }\end{array}$ & $\begin{array}{c}\text { Characteristics of } \\
\text { Study Sample at } \\
\text { Baseline }\end{array}$ & Measure of APA & Measure of Outcome & Main Results \\
\hline & & & $\begin{array}{l}\text { vigorous intensity } \\
\text { physical activity, } \\
\text { measured by } \\
\text { accelerometry }\end{array}$ & & $\begin{array}{l}\text { of follow-up were seen in } \\
\text { schools with aerobic } \\
\text { exercise programs. }\end{array}$ \\
\hline $\begin{array}{l}\text { Fisher et } \\
\text { al } 2011 \\
(20)\end{array}$ & RCT/Scotland/10 weeks & $\begin{array}{l}64 \text { Year } 2 \text { children } \\
\text { (aged } 5-7 \text { y), } 33 \\
\text { boys and } 31 \text { girls }\end{array}$ & $\begin{array}{l}2 \text { Hours of } \\
\text { aerobically focused } \\
\text { physical education } \\
(\mathrm{PE}) \text { per week, } \\
\text { measured by } \\
\text { accelerometry }\end{array}$ & $\begin{array}{l}\text { Cognitive Assessment } \\
\text { System (CAS), } \\
\text { Cambridge } \\
\text { Neuropsychological Test } \\
\text { Battery (CANTAB), } \\
\text { Attention Network Test } \\
\text { (ANT), Conner's } \\
\text { Behavior Rating Scale }\end{array}$ & $\begin{array}{l}\text { Children engaging in } \\
\text { aerobically focused PE } \\
\text { showed no significant } \\
\text { difference in CAS scores, } \\
\text { but CANTAB spatial span } \\
\text { and spatial working } \\
\text { memory errors as well as } \\
\text { ANT accuracy scores were } \\
\text { improved in the } \\
\text { intervention group. }\end{array}$ \\
\hline $\begin{array}{l}\text { Hill et al } \\
2011(21)\end{array}$ & $\begin{array}{l}\text { Crossover/Scotland/2 } \\
\text { weeks }\end{array}$ & $\begin{array}{l}760 \text { Children in } \\
\text { primaries } 4 \text { to } 7 \\
\text { (aged } 8-12 \text { y) }\end{array}$ & $\begin{array}{l}\text { On each cohorts' } \\
\text { scheduled week, } \\
10-15 \text { minutes of } \\
\text { moderately } \\
\text { intensive APA daily }\end{array}$ & Cognitive test battery & $\begin{array}{l}\text { APA had a short-term } \\
\text { positive effect on cognitive } \\
\text { performance, but may } \\
\text { have been due to exercise } \\
\text { enhancing use of memory } \\
\text { (practice). }\end{array}$ \\
\hline $\begin{array}{l}\text { Reed et al } \\
2010(22)\end{array}$ & $\begin{array}{l}\text { RCT/United States/4 } \\
\text { months }\end{array}$ & $\begin{array}{l}155 \text { Children in } 3 r d \\
\text { grade (aged } 7-10 \\
\text { y) }\end{array}$ & $\begin{array}{l}30 \text { Minutes of } \\
\text { integrated APA into } \\
\text { core curriculum, } 3 \\
\text { times per week, } \\
\text { with pedometers to } \\
\text { measure activity. } \\
\text { Evidence supports } \\
\text { walking as } \\
\text { moderate-intensity } \\
\text { APA (23). }\end{array}$ & $\begin{array}{l}\text { Palmetto Achievement } \\
\text { Challenge Tests (PACT), } \\
\text { Standard Progressive } \\
\text { Matrices (SPM), Fluid } \\
\text { Intelligence Tests }\end{array}$ & $\begin{array}{l}\text { Children performing } \\
\text { regular integrated aerobic } \\
\text { activity performed } \\
\text { significantly better on } \\
\text { intelligence testing and on } \\
\text { state tests on social } \\
\text { studies. Scores were also } \\
\text { higher on } \\
\text { English/language arts, } \\
\text { math, and science } \\
\text { achievement tests but not } \\
\text { significant in comparison } \\
\text { to control groups. }\end{array}$ \\
\hline $\begin{array}{l}\text { Shephard } \\
1996(24)\end{array}$ & RCT/Canada/ 6 years & $\begin{array}{l}546 \text { Children from } \\
\text { grades } 1 \text { through } 6 \\
\text { (aged } 5-12 \text { y) }\end{array}$ & $\begin{array}{l}\text { Additional } 1 \text { hour } \\
\text { of aerobic physical } \\
\text { activity daily, with } \\
\text { heart rates } \\
\text { between } 157 \text { and } \\
178 \text { beats per } \\
\text { minute }\end{array}$ & $\begin{array}{l}\text { Goodenough test, } \\
\text { Wechsler Intelligence } \\
\text { Scale for Children } \\
\text { (WISC) }\end{array}$ & $\begin{array}{l}\text { APA enhances (rather } \\
\text { than worsens) academic } \\
\text { performance even if } \\
\text { curriculum time is } \\
\text { reassigned to physical } \\
\text { activity; however, effects } \\
\text { are very small. }\end{array}$ \\
\hline $\begin{array}{l}\text { Stroth et } \\
\text { al } 2009 \\
(25)\end{array}$ & $\begin{array}{l}\text { Crossover/Germany/7 } \\
\text { days }\end{array}$ & $\begin{array}{l}33 \text { Adolescents } \\
\text { (aged } 12-16 y) \text {, } \\
\text { divided into higher- } \\
\text { fit }(n=17) \text { and } \\
\text { lower-fit }(n=16) \\
\text { subgroups }\end{array}$ & $\begin{array}{l}\text { Acute bout ( } 20 \\
\text { min) of moderate } \\
\text { APA, corresponding } \\
\text { to } 60 \% \text { of } \\
\text { individual maximal } \\
\text { heart rate }\end{array}$ & $\begin{array}{l}\text { Modified Eriksen flanker } \\
\text { task, evaluating } \\
\text { executive function } \\
\text { through go/nogo tasks }\end{array}$ & $\begin{array}{l}\text { No reliable effect of acute } \\
\text { exercise on inattention } \\
\text { (missed responses to "go- } \\
\text { trials") or impulsivity } \\
\text { (false alarms in nogo- } \\
\text { trials); however, higher-fit } \\
\text { individuals did perform } \\
\text { better. }\end{array}$ \\
\hline $\begin{array}{l}\text { Tuckman } \\
\text { and } \\
\text { Hinkle } \\
1986(26)\end{array}$ & $\begin{array}{l}\text { RCT/United States/12 } \\
\text { weeks }\end{array}$ & $\begin{array}{l}154 \text { Children in } \\
\text { grades } 4,5, \text { and } 6 \\
\text { (mean ages 9.3, } \\
10.3, \text { and } 11.3, \\
\text { respectively) }\end{array}$ & $\begin{array}{l}\text { Three sessions of } \\
\text { running for } 30 \\
\text { minutes each week }\end{array}$ & $\begin{array}{l}\text { Devereux Elementary } \\
\text { School Behavior Rating } \\
\text { Scale, Alternate Uses } \\
\text { Test, Maze Tracing } \\
\text { Speed Test }\end{array}$ & $\begin{array}{l}\text { Running (aerobic exercise) } \\
\text { had a significant positive } \\
\text { effect on creative capacity } \\
\text { but made no contribution } \\
\text { to behavior or perceptual } \\
\text { functioning. }\end{array}$ \\
\hline
\end{tabular}

Abbreviations: APA, aerobic physical activity; RCT, randomized controlled trial.

Table 2. Critical Appraisal of Randomized Control Studies Reporting Children's Cognitive and Psychosocial Outcomes After Increased Aerobic Activity

\begin{tabular}{|l|l|l|c|}
\hline & & & $\begin{array}{c}\text { Critical } \\
\text { Appraisal: } \\
\text { Jadad Criteria } \\
\text { (range, 0-5) } \\
(16)\end{array}$ \\
\hline Source & Study Strengths & Study Weaknesses & 1
\end{tabular}




\begin{tabular}{|c|c|c|c|}
\hline Source & Study Strengths & Study Weaknesses & $\begin{array}{c}\text { Critical } \\
\text { Appraisal: } \\
\text { Jadad Criteria } \\
\text { (range, 0-5) } \\
(16)\end{array}$ \\
\hline $\begin{array}{l}\text { Crews et al } \\
2004(18)\end{array}$ & $\begin{array}{l}\text { Standardized measure of APA and } \\
\text { outcome; measures used were common } \\
\text { and validated }(27,28) \text {; high internal } \\
\text { reliability of inventories (test retest, a = } \\
0.90 \text { ) }\end{array}$ & $\begin{array}{l}\text { Small number of participants, short follow-up; Beck } \\
\text { Depression Inventory version was not designed for } \\
\text { children; STAI-Y has not been validated in children }\end{array}$ & \\
\hline $\begin{array}{l}\text { Donnelly et } \\
\text { al } 2009 \\
\text { (19) }\end{array}$ & $\begin{array}{l}\text { Large number of participants; long follow- } \\
\text { up; standardized measure of APA and } \\
\text { outcome; WIAT-II validated, reliable, and } \\
\text { commonly used in children (29) }\end{array}$ & None & 2 \\
\hline $\begin{array}{l}\text { Fisher et al } \\
2011(20)\end{array}$ & $\begin{array}{l}\text { Standardized measure of APA and } \\
\text { outcome; CAS previously demonstrated to } \\
\text { be both valid and reliable in children older } \\
\text { than } 4 \text { years with high correlation to IQ } \\
\text { testing (29); Conner's Parent Rating Scale } \\
\text { validated and reliable in children (30) }\end{array}$ & $\begin{array}{l}\text { Small number of participants; short follow-up; Cambridge } \\
\text { Neuropsychological Test Battery (CANTAB) and Attention } \\
\text { Network Test (ANT), Conner's Parent Rating Scale not } \\
\text { validated in children (reliability testing by authors found } \\
\text { limited utility with poor to moderate reliability); fewer than } \\
\text { half the parents returned the Conner's questionnaire }\end{array}$ & 4 \\
\hline $\begin{array}{l}\text { Hill et al } \\
2011(21)\end{array}$ & $\begin{array}{l}\text { Large number of participants; objective } \\
\text { measure of outcome }\end{array}$ & $\begin{array}{l}\text { Short follow-up; no objective measure of APA; cognitive } \\
\text { battery test used modified versions of the Children's Size } \\
\text { Ordering Task, Wechsler Intelligence Scale for Children } \\
\text { (WISC), and Children's Paced Auditory Serial Addition } \\
\text { Task, so validity and reliability cannot be judged }\end{array}$ & 4 \\
\hline $\begin{array}{l}\text { Reed et al } \\
2010(22)\end{array}$ & $\begin{array}{l}\text { Standardized measure of outcome; SPM } \\
\text { has high reliability and is recommended } \\
\text { for children under } 12 \text { years (29) }\end{array}$ & $\begin{array}{l}\text { Short follow-up; did not measure intensity of APA; } \\
\text { Palmetto Achievement Challenge Tests (PACT) not } \\
\text { validated based on scholarly database search or cited in } \\
\text { the article }\end{array}$ & 4 \\
\hline $\begin{array}{l}\text { Shephard } \\
1996(24)\end{array}$ & $\begin{array}{l}\text { Large number of participants; long follow- } \\
\text { up; standardized measure of APA and } \\
\text { outcome; WISC is a commonly used } \\
\text { measure of global intelligence in children } \\
\text { and is both reliable and valid (28) }\end{array}$ & $\begin{array}{l}\text { Goodenough test shows moderate correlation to } \\
\text { intelligence but is best corroborated with other } \\
\text { assessments (28) }\end{array}$ & 0 \\
\hline $\begin{array}{l}\text { Stroth et al } \\
2009(25)\end{array}$ & $\begin{array}{l}\text { Standardized measure of APA and } \\
\text { outcomes }\end{array}$ & $\begin{array}{l}\text { Small number of participants; short follow-up; go/nogo } \\
\text { test only used and previously validated for use in } \\
\text { neurophysiology testing by the authors but not for the } \\
\text { results indicative of executive function, so reliability and } \\
\text { validity in this context cannot be judged (31) }\end{array}$ & 2 \\
\hline $\begin{array}{l}\text { Tuckman } \\
\text { and Hinkle } \\
1986(26)\end{array}$ & $\begin{array}{l}\text { Standardized measure of outcome; } \\
\text { Devereux scale and Alternate Uses Test } \\
\text { reliable }\end{array}$ & $\begin{array}{l}\text { Short follow-up; no standardized measure of APA; Maze } \\
\text { Tracing Speed Test has no reliability information }\end{array}$ & 1 \\
\hline
\end{tabular}

Abbreviations: APA, aerobic physical activity; STAI-Y, State-Trait Anxiety Inventory Form Y; WIAT-II, Wechsler Individual Achievement Test, 2nd edition; CAS, Cognitive Assessment System; IQ, intelligence quotient; SPM, Standard Progressive Matrices Test; WISC, Wechsler Intelligence Scale for Children.

\section{Appendix: Search Strategies}

\section{MEDLINE}

- (Physical Fitness OR Exercise OR Physical Exertion) AND (Mental Health OR Health OR Cognition OR Achievement OR Intelligence)

- Subject Headings used

- Limited to English language, Human, All Children (o-18 y)

- 479 hits

\section{SPORTDiscus}

- (Physical Activity OR Exercise OR Cardiovascular OR Aerobic) AND (Health OR Mental Health OR Cognition OR Achievement OR Intelligence OR Intelligence Tests) AND (Children OR Teens OR Child OR Students)

- Keyword search

- Limited to English language

- 54 hits

\section{EMBASE}


- (Physical Activity OR Exercise OR Aerobic OR Fitness) AND (Achievement OR Cognition OR Health OR Intelligence OR Mental Health)

- Subject Headings used

- Limited to Human, English language, and Child (unspecified age). MEDLINE journals excluded.

- 58 hits

Cochrane

- (Exercise OR Physical Fitness OR Aerobic OR Physical Exertion) AND (Cognition OR Mental Health OR Achievement OR Intelligence OR Intelligence Tests)

- Keywords used

- 3 hits

PsycINFO

- (Physical Activity OR Exercise OR Fitness) AND (Mental Health OR Health OR Cognition OR Intelligence OR Intelligence Test)

- Major Subject Headings used

- Limited to Childhood (birth-12 y), Adolescence (13-17 y), School Age (6-12 y) and English language

- 639 hits

The opinions expressed by authors contributing to this journal do not necessarily reflect the opinions of the U.S. Department of Health and Human Services, the Public Health Service, the Centers for Disease Control and Prevention, or the authors' affiliated institutions.

he RIS file format is a text file containing bibliographic citations. These files are best suited for import into bibliographic

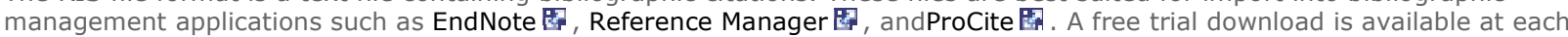
application's web site.

For Questions About This Article Contact pcdeditor@cdc.gov

Page last reviewed: October 24, 2013

Page last updated: October 24, 2013

Content source: National Center for Chronic Disease Prevention and Health Promotion

Centers for Disease Control and Prevention 1600 Clifton Rd. Atlanta, GA 30333, USA

80o-CDC-INFO (80o-232-4636) TTY: (888) 232-6348 - Contact CDC-INFO

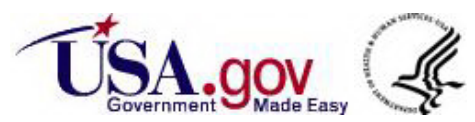

